\title{
Continuing health education for qualification of professional practice in Psychosocial Care Centers
}

\author{
Educação Permanente em Saúde para qualificação da prática profissional em Centros de Atenção Psicossocial
}

Educación en salud permanente para la calificación de la práctica profesional en Centros de Atención Psicosocial

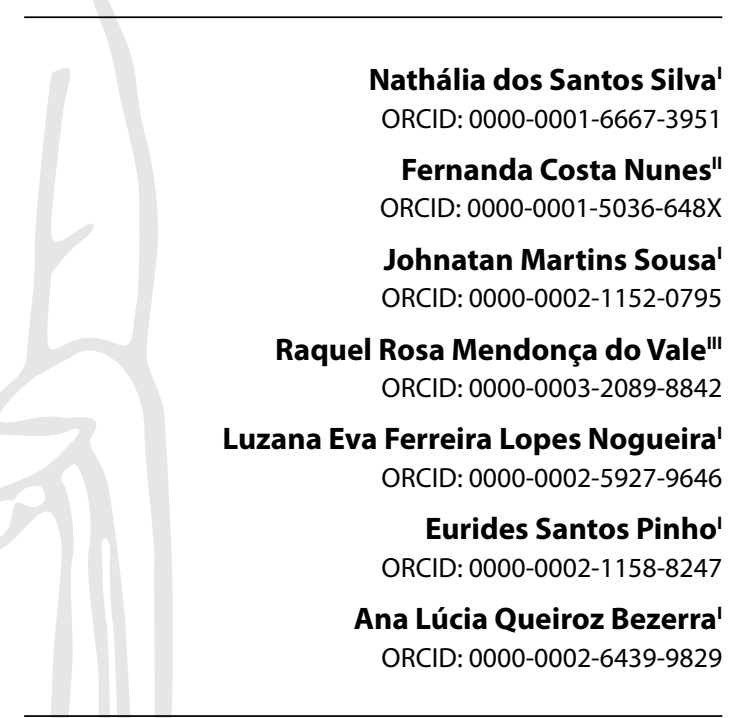

'Universidade Federal de Goiás. Goiânia, Goiás, Brazil. "Secretaria de Estado da Saúde de Goiás. Goiânia, Goiás, Brazil. "'Centro Universitário de Mineiros. Goiânia, Goiás, Brazil.

How to cite this article:

Silva NS, Nunes FC, Sousa JM, Vale RRM, Nogueira LEFL, Pinho ES, et al. Continuing health education for qualification of professional practice in Psychosocial Care Centers. Rev Bras Enferm. 2021;74(0):e20210155. https://doi.org/10.1590/0034-7167-2021-0155

Corresponding author: Nathália dos Santos Silva E-mail: nathaliassilva@ufg.br

EDITOR IN CHIEF: Antonio José de Almeida Filho ASSOCIATE EDITOR: Ana Fátima Fernandes

Submission: 07-07-2020

Approval: 04-14-2021

\section{ABSTRACT}

Objective: to describe and analyze a strategy of continuing health education to manage the quality of professionals' work in Psychosocial Care Centers. Method: this is a researchintervention carried out in Psychosocial Care Centers in the state of Goiás, Brazil, with the participation of 58 professionals. Data were collected in 2016 through seminars and workshops. Thematic content analysis was carried out. Results: professionals associated the Singular Therapeutic Project to the record of performed procedures and described the need to develop skills for correct completion and interpretation of procedures, use of a record software and computerization of processes. The qualification strategy used was considered to be effective in making improvements to the work carried out feasible. Final Considerations: the study presents a qualification strategy for community mental health service teams to guide the care model for territorial care centered on users.

Descriptors: Education, Continuing; Community Mental Health Services; Mental Health Services; Inservice Training; Professional Practice.

\section{RESUMO}

Objetivo: descrever e analisar uma estratégia de Educação Permanente em Saúde para gestão da qualidade do processo de trabalho dos profissionais em Centros de Atenção Psicossocial. Método: pesquisa-intervenção, realizada em Centros de Atenção Psicossocial do estado de Goiás, Brasil, com a participação de 58 profissionais. Os dados foram coletados em 2016 por meio da realização de seminário e oficinas. Foi feita análise temática de conteúdo. Resultados: os profissionais associaram o Projeto Terapêutico Singular ao registro dos procedimentos realizados e descreveram a necessidade do desenvolvimento de competências para preenchimento correto e interpretação dos procedimentos realizados, uso do software de registro e a informatização dos processos. A estratégia de qualificação utilizada foi considerada como efetiva para viabilizar melhorias ao trabalho realizado. Considerações Finais: o estudo apresenta uma estratégia de qualificação das equipes de serviços comunitários de saúde mental para orientar o modelo de atenção para o cuidado territorial, centrado no usuário. Descritores: Educação Continuada; Serviços Comunitários de Saúde Mental; Serviços de Saúde Mental; Capacitação de Recursos Humanos em Saúde; Prática Profissional.

\section{RESUMEN}

Objetivo: describir y analizar una estrategia de Educación Permanente en Salud para gestionar la calidad del proceso de trabajo de los profesionales en los Centros de Atención Psicosocial. Método: investigación-intervención, realizada en Centros de Atención Psicosocial del estado de Goiás, Brasil, con la participación de 58 profesionales. Los datos se recopilaron en 2016 a través de seminarios y talleres. Se realizó un análisis de contenido temático. Resultados: los profesionales asociaron el Proyecto Terapéutico Singular al registro de los procedimientos realizados y describieron la necesidad de desarrollar habilidades para la correcta cumplimentación e interpretación de los procedimientos realizados, el uso del software de registro y la informatización de los procesos. La estrategia de calificación utilizada se consideró eficaz para permitir mejoras en el trabajo realizado. Consideraciones finales: el estudio presenta una estrategia de capacitación de los equipos de servicios comunitarios de salud mental para orientar el modelo de atención para el cuidado territorial, centrado en el usuario.

Descriptores: Educación Continua; Servicios Comunitarios de Salud Mental; Servicios de Salud Mental; Capacitación de Recursos Humanos en Salud; Práctica Profesional. 


\section{INTRODUCTION}

Psychosocial Care Centers (CAPS - Centros de Atenção Psicossocial) are community mental health services of the Brazilian Unified Health System (SUS - Sistema Único de Saúde) that must be articulated with other Psychosocial Care Network services to care for people with severe and persistent mental disorders and for people with problems related to the use of alcohol and other drugs ${ }^{(1-2)}$.

The work process in these services must be based on the psychosocial care framework, which is guided by Brazilian Psychiatric Reform assumptions, and which comprises people with mental distress in a unique way and insertedto in a given context. This model alters the biomedical paradigm, as it understands existencesuffering as opposed to the binomial disease-cure, involves social control and legal apparatus that regulate substitute services and highlights the concept of comprehensive care and the insistent need to promote activities in the territory, to overcome the collective imagination about madness ${ }^{(3-4)}$.

In this context, for manage care at CAPS, it is recommended to develop Unique Therapeutic Projects (PTS - Projeto Terapêutico Singular) that enable the proposition of unique care strategies to assist individuals/families through a collaborative, participatory practice, formative and shared between persons in psychological distress, their family, their reference technician and other multidisciplinary team professionals according to their demands and needs ${ }^{(5-6)}$.

"The Brazilian Psychiatric Reform has among workers one of the main driving forces of its constitution, support, criticism and transformation"(7). However, despite the theoretical-conceptual advances in the psychosocial care model and the guidance for the production of care guided by the PTS, it is still possible to perceive difficulties, on the part of professionals, to reconfigure their competences through the expansion of actions and diversification of arsenal therapeutic activities developed ${ }^{(8-10)}$.

Considering this, studies point to the need to reinforce comprehensive and community-based care for users with mental disorders and their families, in line with the reformist precepts, through greater investments in the structure of services, institutional support, training and management commitment in the continuing education processes ${ }^{(8-9)}$.

To take a look at the work processes at CAPS, we consider the necessary understanding of continuing health education (CHE), which is aimed at the multidisciplinary health team and aims at transformations of professional practices, with a view to qualifying access, humanization care and improving the management capacity of SUS ${ }^{(11)}$. Therefore, training based on the work process reflection will be necessary through a joint construction, not imposed and that encompasses psychosocial attention ${ }^{(12)}$.

Moreover, it is worth highlighting the actions that are developed at CAPS described and defined as ordinance procedures, considering that they are procedures that are potentially more sensitive to the psychosocial guidelines for the functioning of these services ${ }^{(9,13)}$. Considering this premise and the challenge of developing strategies to qualify the work processes in CAPS that make sense and change professional practice in a manner consistent with that of the psychosocial model, in the present study, a description and analysis of a CHE strategy for quality management of health professionals' work in CAPS will be made.

\section{OBJECTIVE}

To describe and analyze a strategy of Continuing health education to manage the quality of health professionals' work in Psychosocial Care Centers.

\section{METHOD}

\section{Ethical aspects}

The research complied with the ethical precepts mentioned in Resolution 466/2012 of the Brazilian National Health Council (Conselho Nacional de Saúde) and obtained a favorable opinion from the Institutional Review Board of Hospital das Clínicas of Universidade Federal de Goiás, with Certificate of Presentation for Ethical Appreciation. All participants signed the Informed Consent Form; to ensure anonymity, participants' reports were identified by the codification of CAPS and the participating professional.

\section{Type of study}

This is a study of qualitative approach of research-intervention type. This type of research encompasses the investigative process, the relationships built between the various actors, the methods and technologies used throughout the study, in addition to working in a group liable to chang $\mathrm{e}^{(14)}$. The survey met the items recommended by the COnsolidated criteria for REporting Qualitative research (COREQ) ${ }^{(15)}$.

\section{Study setting}

The study was carried out in seven CAPS in three municipalities in the state of Goiás, which had 61 CAPS authorized by the Ministry of Health until the time of data collection. The municipalities that had CAPS enabled for more than two years were drawn. In the selected municipalities, all CAPS were included.

\section{Data source}

In all, the seven CAPS had 67 professionals eligible for research; however, 58 professionals who had worked at CAPS for at least six months, with complete college education and who were in professional practice at the time of data collection participated in the study. The other professionals were excluded, because they were not available to participate in all the steps provided for in the study.

\section{Data collection and organization}

Data collection was carried out in three stages from March to October 2016. Considering the reference of $\mathrm{CHE}^{(11)}$, the first step consisted of carrying out a focus group in each CAPS to understand the use of instruments for recording service procedures, which are the Individualized Outpatient Production Bulletin (BPA-I - Boletim de Produção Ambulatorial Individualizado), Consolidated Outpatient Production Bulletin (BPA-C) and Outpatient Health Actions Record (RAAS - Registro das Ações Ambulatoriais de Saúde $)^{(9,13)}$. In this stage of the research, it was possible to identify professionals' lack of knowledge about the definition of CAPS procedures, about the instruments and forms of record and 
about the need and objective of informing the data ${ }^{(9)}$.

The second stage consisted of the $1^{\text {st }}$ Seminar on Monitoring and Assessment of the Psychosocial Care Network in the state of Goiás, in June 2016, at the State Health Council. The Seminar's goal was to inform and guide about the conception, meaning and importance of assessing quality of health services as well as to discuss conceptual and operational aspects of record instruments and each CAPS procedure. The Seminar enabled the participation of all CAPS professionals in Goiás, in addition to the study participants, on their initiative.

The first two stages were important to elucidate conceptual and operational aspects of record instruments used in CAPS and of each procedure provided for in ordinances. The guidance on the instruments was fundamental, as there was a lack of knowledge about them, mainly about BPA-C and BPA-I. Additionally, each procedure was discussed in order to broaden the understanding and interpretation of its definitions.

The third stage was carried out after the seminar and construction of theoretical knowledge, with the realization of seven workshops, one in each CAPS. Based on CAPS procedures established by Ordinance $\mathrm{MoH} 854 / 2012^{(13)}$, participants collectively produced the PTS using a technique developed for this purpose, called "Flower Pyramid Scheme".

Understanding the PTS as a tool to systematize psychosocial care and descriptions of CAPS procedures as a possibility to assist in proposing interventions with users, workshops were planned to discuss the PTS elaboration and, at the same time, to provide another functionality for concreteness of records beyond purely bureaucratic issues.

During each workshop, participants, in groups, were invited to choose cases of users attended or in attendance at CAPS, based on the difficulty they had to conduct the therapy or on the efficiency of the results achieved. Then, the following questions were asked: in the CAPS practice, how do you build each users' PTS? Do they share the case and the actions carried out and/or planned in this user's PTS? Do the actions carried out and/or planned in this user's PTS relate to CAPS procedures described in ordinance ${ }^{(13)}$ ?

As the participants described and answered the last question, the workshop facilitators related the actions to the corresponding RAAS, BPA-I and BPA-C procedures. For this end, they used the construction of a flower as a visual resource, in which each petal indicated a procedure, the procedure number and the record instrument with the description on the back. Often, professionals were unable to relate the action to the procedure and the researchers made the relationship by informing and clarifying the definition of the procedure. Figure 1 illustrates this feature used in the workshops.
After the presentation of each group, the therapeutic project was discussed and clarifications were made on RAAS and BPA-C and BPA-I procedures. This moment was opportune for the participants to verify that many actions were subject to records that were not being made and to envision more and better interventions in the case, in addition to understanding the importance of records.

All stages of data collection were recorded using digital recorders, photographs and notes in the researchers' logbooks. To guarantee participants' anonymity, they were identified with the letter $\mathrm{P}$, followed by the number following the speeches.

\section{Data analysis}

The researchers' transcription of audios, photographs and notes in a logbook were subjected to content analysis ${ }^{(16)}$ with the help of software ATLAS.ti 6.2, being structured in pre-analysis, material exploration, treatment and interpretation of results. In pre-analysis, the material became operational with organization of photographs and reading of transcripts. Material exploration was the second phase, in which categories, record units and, consequently, context units were identified. In the third phase, treatment and interpretation of results, with the help of software, networks of relationships were built between the recording units that facilitate the understanding of the data.

\section{RESULTS}

The thematic categories that emerged from content analysis were: Qualification required to record procedures in Psychosocial Care Center; Learning about procedure records from Psychosocial Care Center; The meaning of procedures and their insertion in a mental health care line. It is worth mentioning that the results presented were obtained from data analysis from the 2 nd and 3rd stages of data collection. 


\section{Qualification required to record procedures in Psychoso- cial Care Center}

Participants presented considerations that can facilitate the recording of information about the work process at CAPS. All participants emphasized the need to develop competencies, especially knowledge and skills, to operationalize the records, through training, so that they understand the purpose of records, the correct way to complete them, the software operationalization and so that make a proper interpretation of the definition of procedures. The need for qualification by the participants was closely linked to the development of encouragement and motivation for the use of the instruments.

I think that as RAAS is a reality and they will not be able to change, at least, in the medium term. We should understand how to do it right, how to use it, understand its scope in a clearer way, not according to our assumptions. (CAPS2 P5)

The only training we had was how to fill the system, how to export. Not related to the meaning of the procedures. But only for the administrative. There are people who do it and who have not received any training. (CAPS3 $\mathrm{P} 1$ )

We need to make it clearer to us what these codes are, how this system is reversed for us, what is the purpose. As CAPS is more of a psychosocial issue, it has to emphasize more these issues of actions in the territory, so that the professional sees its importance for the territory. (CAPS5 P6)

\section{Learning about records of Psychosocial Care Center procedures}

Considering professionals' lack of knowledge about the record of CAPS procedures ${ }^{(9)}$ and the intervention carried out to meet the need for qualification, the data in this category pointed out the contribution of actions to improve professional practice. The record units included in this category were "contribution from the Seminar", "makes sense of professional work possible" and "expanded record possibilities", as the following context units illustrate:

We saw the importance of this correct filling, because it is he who will give the production data. (CAPS2 P7)

I think it opened our eyes to understand that it is not only: Ah, my service is only proven by completing the RAAS, it showed us that it is essential even for the collection of data for assessment of service. (CAPS6 P9)

It was really cool to hear! And you know what I liked the most? It was to know the concepts of each procedure. (CAPS3 P5

It made more sense and gives more motivation after we discussed it. Due to the difficulties of understanding and interaction and without access to training, it ended up becoming an annoying instrument. (CAPS7 P5)

We printed the instruments and put them in our folder so that when we are going to fill them out, we think better: Is this activity within this procedure? For us to fill in correctly, because we were filling in codes that sometimes did not contemplate the activities that were being done and there are codes that better contemplate the activities that we carry out within CAPS, so this has improved a lot for us. (CAPS2 P4)

It is interesting that, before we were aware of these actions, we only recorded group, individual care and family care were so poor...? Nowadays, we are aware of all the actions, we see how much we articulate, how much we do for each one of them. (CAPS 3 P9)

Participants positively assessed the Seminar, highlighting the knowledge related to the use of records as a tool for monitoring indicators of evidence of work developed at CAPS, in addition to broadening the understanding of concepts of records. Many professionals were impressed with the personal lack of knowledge about the description of procedures and assessed the strategy adopted in CHE as very timely.

The reports show that some professionals perceived limitations in the use of procedure records, and, after the seminar, they began to understand that, if carried out properly, there would be greater recognition of psychosocial practices as well as recognizing many possibilities of recording the activities developed that, until then, they were unaware.

For professionals, the difficulties presented for qualifying the record of actions could be minimized if there was a process of training professionals on the procedures and operability of the instruments and information system, in addition to the possibility of appropriating the data for the purpose of analyzing the CAPS work process.

\section{The meaning of procedures and their insertion in a mental health care line}

This category refers to professionals' understanding of procedures and their association with a line of care developed in the context of mental health and the contribution of $\mathrm{CHE}$ as an indicator of the result of assessment and qualification of records. The record units that illustrate this category were "directs the work", "the result of continuing education process", "possibilities for interventions". The following context units illustrate this category:

So, I think it guides too! RAAS guides our function, what are the activities that we have to carry out within our unit, at least that is what is expected. (CAPS6 P2)

It became clear to us what these codes are, how this system is reversed for us, what is the purpose. As CAPS is more of a psychosocial issue, these issues of actions in the territory have to be emphasized more so that the professional sees the importance of it going to the territory. (CAPS4 P9)

I think it has improved, because we had other ideas to facilitate this filling in the RAAS, which was one of the biggest difficulties that we raised. (CAPS4 P6)

Having representation from the municipality and the State made us believe. That was too good, because I had never seen it around here. (CAPS6 P2)

I was used to talking to the management [State Mental Health Management] and talking about the difficulties, but it was good to involve the coordination of the municipality (CAPS2 P7) 
I think it has improved a lot, because we had other ideas to facilitate the PTS preparation and this filling in RAAS, which was one of the biggest difficulties that we raised (CAPS4 P3)

We realized that RAAS has several possibilities that need to be consulted more (CAPS 7 P5)

Because now they do activities abroad, professional courses, painting, music. At first, the family thinks it is necessary for them to stay here and we have been working to raise their awareness that this [CAPS] is not everything and it has worked out! Here is a part and that we need to leave space on his agenda to have a life abroad (CAPS7 P3)

Carrying out workshops in the services themselves allowed to consider the service's specificities in the discussions, since CAPS teams of different types and different municipalities participated. Furthermore, they pointed out that, upon receiving the share in the service, they avoided moving to the state capital.

Some participants emphasized a closer relationship with the state management than with the municipal mental health coordination to answer questions and make clarifications, since this should be closer to the teams. In any case, they highlighted the importance of managers' involvement in CHE actions.

Professionals' reports illustrate the result of this intervention, considering that the $\mathrm{CHE}$ process was significant in providing professionals with motivation to systematize the procedure records. Moreover, they point out meanings related to assessment of psychosocial practice that is developed in CAPS.

\section{DISCUSSION}

The proposal of this technique with flowers considered the need for the methodology to be problematizing, creative, provocative, in order to lead professionals to become aware of the problem and recognize themselves in them. Participants were encouraged to report cases and identify users' needs. The critical reflection of this information enabled the establishment of therapeutic goals, proposal of interventions and the relationship with the list of procedures described in ordinance. With the use of flowers to illustrate the procedures, each petal represents a recorded procedure. It happened that many flowers had few petals. The discussion of PTS linked to the procedures made flowers robust in the face of the many possibilities of performing record.

The record illustration of procedures before and after, originating from a properly prepared PTS, was impactful to professionals, as they realized that much of what was being developed was not being recorded or there were other possibilities for interventions that had not been previously thought. Workers' "discomforts in their daily work" were then experienced, which are indispensable conditions for a person or an organization to decide to change or incorporate new elements to their practice when realizing that the current way of doing or thinking is insufficient or unsatisfactory to cope with the challenges of health work ${ }^{(17)}$.

The discussion of users'PTS, prepared by the CAPS team itself, made it possible for the $\mathrm{CHE}$ process to be structured based on concrete elements of reality experienced and through exchange of everyday experiences of people involved. In this context, the strategy of associating the record of procedures with PTS arose from the participants' observation that knowledge and skill in the record of procedures would foster PTS systematization.

It is considered that PTS provides professionals with the ability to reflect on their own practice, whether individual or collective, to recognize their weaknesses and potentialities, needs and demands, problems and possibilities, to bring about the necessary change in psychosocial care ${ }^{(18)}$, the team being indispensable in mediating the relationship between user, family, health services and territory ${ }^{(6)}$. Still, problematizing means "thinking about practice", which presupposes breaking with the individual logic to think about the team ${ }^{(19)}$.

During the CHE process, in addition to the development of a more robust PTS, professionals began to realize the need for articulation with other devices in the territory to provide comprehensive care to users. Thus, in addition to understanding the meaning of procedures, they started to differentiate the record instruments (RAAS and BPA-C).

Thus, professionals were able to perceive that the knowledge of procedures established in ordinance enables the discussion of work process, allowing assessing the work developed at CAPS. The understanding of procedures that can be recorded in RAAS is related to the mental care line and PTS. Analysis of data from the first stage of data collection showed that the procedures that are recorded in BPA-C contribute to the assessment of CAPS, as devices for activating networks, through the interlocution between professionals and services in a network ${ }^{(9)}$.

RAAS came to be understood by professionals as a portrait of a user's PTS, and the data from the BPA-C instrument can demonstrate CAPS articulation with other health services and the territory, in addition to promoting the role of users. Both reflect CAPS Institutional Therapeutic Project. This is fundamental because, for the effectiveness of the psychosocial care model, it is not enough to just reformulate spaces, therapeutic approaches or expand the technical team. This process requires the reflection of knowledge and practices that propose to be deinstitutionalizing and directed to psychosocial care ${ }^{(18)}$.

$\mathrm{CHE}$ also enabled professionals to broaden their understanding of PTS and the need to record procedures, in addition to a purely bureaucratic process, as a possibility to instrumentalize and highlight the work that is developed by professionals and to assess CAPS.

Considering that educational actions, such as training, still prevail among professionals ${ }^{(20)}$, and with the aim of treading new training paths for the re-signification of previous punctual, fragmented and verticalized experiences ${ }^{(7,21)}$, the seminar did part of an expanded qualification process and was conducted by specialists with experience in assessment, CAPS work process and mastery of instruments and record system.

The content that guided the discussions throughout the seminar promoted by this research was contextualized from problematization of data, the senses and the meanings originated from the focus groups in the first stage of data collection. Thus, as a constructivist reference for meaningful learning, $\mathrm{CHE}$ is established according to the frequency and spaces in which the activities are developed; based on the problematization of real and everyday issues mediated by the sharing of knowledge to solve problems and manage challenging situations ${ }^{(21-23)}$. 
In addition to a seminar, another CHE strategy was the holding of workshops at CAPS, based on the pressing need to problematize daily lives with the possibility of identifying the potential of professionals for new educational practices in health and for the strengthening of $\mathrm{CHE}$ and the model assistance. It is worth emphasizing that, in $\mathrm{CHE}$, learning needs to make sense in their daily practices, with transformation based on critical reflection on the reality experienced by professionals working in the health service network ${ }^{(19-20,23)}$.

The workshops made it possible to consider service's specificities, since CAPS teams of different types and different municipalities participated. With the involvement of all the team's professionals, unlike the Seminar, which required the displacement to the state capital, it was not possible for everyone. For Ceccim ${ }^{(17)}$, when analyzing a situation in a contextualized way, we are better and more likely to discover the complexity of its explanation and to propose articulated interventions. In the workshops, there was the territory identification of specificities and all the political and structural implications of services. Realities of care and service management in municipalities in the countryside of the state are different from large cities, because the teams are closer to the territory and to management; however, they have less access to the training process. Facts imply the work process of services and justify the invitation to the mental health coordinators of the municipalities to participate in the workshops so that it was possible to clarify aspects related to the management of the data originated by the records made in CAPS and deconstruction of the idea of financial transfer by procedures.

CHE proposes the collective construction of new work strategies committed to the principles and guidelines of SUS and to the needs of each region by problematizing everyday practices, aiming to recover actions and develop autonomy and participation ${ }^{(24)}$.

In this way, it was possible to bring together municipal managers, state managers and mental health teams from CAPS, which contributed to exercising the $\mathrm{CHE}$ process. The results showed the participation of the state management as an institutional supporter of the municipalities and teams involved with a positive assessment. The notion of collegiate management for in-service education causes everyone to be invited to participate in a joint operation in which they enjoy the protagonism and collective production ${ }^{(25)}$. This is a challenge for $\mathrm{CHE}$ processes, as it requires building relationships that promote a break with conservative, vertical and authoritarian practices. It is essential to build institutional devices to establish more democratic and participatory structures ${ }^{(23-24)}$.

The basis of health work should be composed of spaces for discussing clinical cases, the work process and the difficulties faced. Thus, the active participation of professionals in group strategies can favor the power of negotiation between different interests. Thus, contact with diverse ways of dealing with issues in daily practice favors the bet on building this perspective together with users, in the management of their PTS, in negotiation with reference professionals and in the experience in group processes in services ${ }^{(7,23)}$.

Consolidating new mental health practices with the use of care technologies is an innovation in opposition to the limited medical-centered and fragmented therapies ${ }^{(23)}$. A relevant guideline of the psychosocial care model is the use of the territory in care production. Therefore, it is essential that, in the PTS, actions are planned in the community that provide social reintegration. RAAS carried out at CAPS encourage teams to occupy the territory and allow the record of actions developed inside and outside CAPS.

The technical-assistance dimension of the psychosocial care model $^{(3)}$ highlights the construction of a network of articulated services with spaces for care and dialogue. Thus, the procedures subject to record include institutional actions to articulate and sustain the care network, being carried out in an intersectoral manner and recorded in BPA-C. Most participants were unaware of this information and even criticized the impossibility of recording matrix support actions, network articulations, harm reduction actions.

The contributions of practice are, therefore, problematized and are configured as a way to stimulate the debate and thematic exploration ${ }^{(18,23-24)}$. The recognition, by the research participants, of psychosocial practices that can be recorded, as well as the possibility of recording network articulation actions and strengthening the role of users, favors the construction of PTS committed to the dimensions of psychosocial care.

CAPS line of care and understanding, as a network articulation device, contribute to the analysis and/or elaboration of CAPS Institutional Therapeutic Projects. Articulation with other services through therapeutic plans, extended meetings, exchange of experiences and agreement on flows are powerful spaces for $\mathrm{CHE}$.

The transformation of the mental health care model is a complex social process that requires social participation, an epistemological review of care concepts. In this context, this process can be achieved through PTS discussion, with practices centered on multidisciplinary teamwork, participation of users and their families and expansion of actions beyond CAPS, promoting reflection on the work process in this important segment of mental health ${ }^{(18)}$.

\section{Study limitations}

The study limitation is related to the impossibility of carrying out the workshops in all CAPS in the state of Goiás, Brazil, through intervention research as a result of the logistics for displacement of professionals.

\section{Contributions to nursing and nursing}

The main contribution of this work to mental health is related to the proposition of an CHE strategy to qualify users' PTS, the Institutional Therapeutic Project of CAPS and, consequently, of records of procedures. Still, it highlights the possibility of elaborating and assessing PTS based on CAPS procedure record instruments, considering the reformist precepts that reinforce mental health practices in the territory.

Nursing represents an important professional category in the context of community mental health services, and it is essential to develop management skills like these to strengthen psychosocial care.

\section{FINAL CONSIDERATIONS}

This research report describes and analyzes an CHE process (at times, even artisanal) for the qualification of CAPS work processes that enabled transformations in the setting, as they 
favored conceptual ruptures, facilitated the expression of creativity, involved management at municipal levels and state and, consequently, generated autonomy for subjects.

In order to broaden the understanding and look at mental health as an integrated care to the practice and that takes into account subject comprehensiveness, it will be necessary to consider $\mathrm{CHE}$ as a strategy capable of generating reflective processes and covering comprehensive mental health care. person and family. Professionals positively assessed the entire CHE process, as it helped to understand the records, deconstructed the idea of associating the registry for financial transfer and using the list of procedures as an instrument that minimally guides what the teams of a CAPS need to develop, i.e., it establishes a line of mental health care. In this regard, professionals identified the possibility of making more robust PTS and even reviewing Institutional Therapeutic Projects. The attitude of just discussing these procedures in a team was once a possibility of reflecting on the work process, according to the psychosocial logic, in addition to identifying gaps in care.

However, it is emphasized that the teams need to use a list of CAPS procedures as a guideline for a flexible mental health care line that considers the context of service. This is essential so that workers do not exempt themselves from the function of elaborating and managing PTS and do not admit ready-made guidelines.

Finally, we highlight the type of research-intervention as potent for bringing researchers closer to the object of study and for enabling the construction of spaces for collective problematization together with training practices and timely return of results to the group of study participants. Professionals' understanding of the record process of actions developed at CAPS or other devices in the territory is essential to defend the model of psychosocial care, since we still have two contradictory models of mental health care in the country and one Psychiatric Reform to be consolidated.

\section{FUNDING/ACKNOWLEDGMENT}

We thank the State Department of Health of Goiás, for contributing to the data collection logistics, and the Mental Health Management psychologist of this department, Alexandra Lenina Falcão Moreno, and Acelo Nardini, for the technical collaboration in data collection.

Acknowledgments are also extended to the Research Support Foundation of Goiás State, for the granting PhD scholarship to one of the authors.

\section{REFERENCES}

1. Rodovalho ALP, Pegoraro RF. The Center for Psychosocial Care according to family members of users: a study from the therapeutic itineraries. SMAD Rev Eletron Saude Ment Alcool Drogas. 2020;16(1):1-8. https://doi.org/10.11606//issn.1806-6976.smad.2020.150161

2. Ministério da Saúde (BR). Centros de atenção psicossocial e unidades de acolhimento como lugares da atenção psicossocial nos territórios: orientações para elaboração de projetos de construção, reforma e ampliação de CAPS e de UA [Internet]. Brasília, DF: MS; 2015 [cited 20 Apr 2020]. Available from: http://bvsms.saude.gov.br/bvs/publicacoes/centros_atencao_psicossocial_unidades_acolhimento.pdf

3. Amarante P. Saúde mental e atenção psicossocial. 4a ed. Rio de Janeiro: Fiocruz; 2015.

4. Beutinger D, Limberger JB. Interfaces entre a assistência farmacêutica e o Projeto Terapêutico Singular sob o olhar de profissionais de um CAPSi. Disciplinarum Sci. 2019;20(2):239-56. https://doi.org/10.22456/2238-152X.83043

5. Grigolo TM, Peres GM, Garcia Jr CA, Rodrigues J. O projeto terapêutico singular na clínica da atenção psicossocial. Cad Bras Saude Ment [Internet]. 2015[cited 2019 Jun 28];7(15):53-73. Available from: http://incubadora.periodicos.ufsc.br/index.php/cbsm/article/view/2951

6. Silva JR, Guazina FMN, Pizzinato A, Rocha KB. O "singular" do projeto terapêutico: (im)possibilidades de construções no CAPSi. Rev Polis Psique [Internet]. 2019 [cited 24 Apr 2020];9(1):127-46. Available from: https://www.seer.ufrgs.br/PolisePsique/article/view/83043/52412

7. Emerich BF, Onocko-Campos R. Formação para o trabalho em saúde mental: reflexões a partir das concepções de sujeito, coletivo e instituição. Interface (Botucatu). 2019;23:e170521. https://doi.org/10.1590/Interface.170521

8. Pinho ES, Souza ACS, Esperidião E. Working processes of professionals at psychosocial care centers (CAPS): an integrative review. Cienc Saude Colet. 2018;23(1):141-52. https://doi.org/10.1590/1413-81232018231.08332015

9. Silva NS, Camargo NCS, Bezerra ALQ. Assessment of the procedures record by professionals of psychosocial care centers. Rev Bras Enferm. 2018;71(suppl 5):2191-8. https://doi.org/10.1590/0034-7167-2017-0821

10. Clementino FS, Miranda FAN, Pessoa Jr JM, Marcolino EC, Silva Jr JA, Brandão GCG. Atendimento integral e comunitário em saúde mental: avanços e desafios da reforma psiquiátrica. Trab Educ Saude. 2019;17(1):e0017713. https://doi.org/10.1590/1981-7746-sol00177

11. Gonçalves CB, Pinto ICM, França T, Teixeira CF. The resumption of the implementation process of the national permanent health education policy in Brazil. Saude Debate. 2019;43(spe 1):12-23. https://doi.org/10.1590/0103-11042019s101

12. Rézio LA, Fortuna CM, Borges FA. Tips for permanent education in mental health in primary care guided by the institutional socio-clinic. Rev Latino-Am Enfermagem. 2019;27:e3204. https://doi.org/10.1590/1518-8345.3217.3204

13. Ministério da Saúde (BR). Portaria n॰ 854, de 22 de agosto de 2012. Altera a Tabela de Procedimentos, Medicamentos, Órteses, Próteses e Materiais Especiais do Sistema Único de Saúde [Internet]. 2012[cited 2017 Feb 20]. Available from: http://bvsms.saude.gov.br/bvs/ saudelegis/sas/2012/prt0854_22_08_2012.html

14. Mendes R, Pezzato LM, Sacardo DP. Research and intervention in the promotion of health: methodological challenges of researching "with". Cien Saude Colet. 2016;21(6):1737-46. https://doi.org/10.1590/1413-81232015216.07392016 
15. Tong A, Sainsbury P, Craig J. Consolidated criteria for reporting qualitative research (COREQ): a 32 -item checklist for interviews and focus groups. Int J Qual Health Care. 2007;19(6):349-57. https://doi.org/10.1093/intqhc/mzm042

16. Bardin L. Análise de conteúdo. 4ah ed. Lisboa: Edições 70; 2010.

17. Ceccim RB. Educação Permanente em saúde: desafio ambicioso e necessário. Interface (Botucatu). 2005;16(9):161-77. https://doi. org/10.1590/S1414-32832005000100013

18. Vasconcelos MGF, Jorge MSB, Catrib AMF, Bezerra IC, Franco TB. Projeto terapêutico em saúde mental: práticas e processos nas dimensões constituintes da atenção psicossocial. Interface (Botucatu). 2016;20(57):313-23. https://doi.org/10.1590/1807-57622015.0231

19. Cardoso MLM, Costa PP, Costa DM, Xavier C, Souza RMP. The national permanent health education policy in public health schools: reflections from practice. Cienc Saude Colet. 2017;22(5):1489-500. https://doi.org/10.1590/1413-81232017225.33222016

20. Silva KL, Matos JAV, França BD. The construction of permanent education in the process of health work in the state of Minas Gerais, Brazil. Esc Anna Nery. 2017;21(4):e20170060. https://doi.org/10.1590/2177-9465-ean-2017-0060

21. Bispo Jr JP, Moreira DC. Educação permanente e apoio matricial: formação, vivências e práticas dos profissionais dos núcleos de apoio à saúde da família e das equipes apoiadas. Cad Saude Publica. 2017;33(9):e00108116. https://doi.org/10.1590/0102-311×00108116

22. Lemos CLS. Educação permanente em saúde no Brasil: educação ou gerenciamento permanente? Cienc Saude Colet. 2016;21(3):913-22. https://doi.org/10.1590/1413-81232015213.08182015

23. Nunes FC, Caixeta CC, Pinho ES, Souza ACS, Barbosa MA. Group technology in psychosocial care: a dialogue between action-research and permanent health education. Texto Contexto Enferm. 2019;28:e20180161. https://doi.org/10.1590/1980-265x-tce-2018-0161

24. Sarreta FO. Educação permanente em saúde para os trabalhadores do SUS. São Paulo: Cultura Acadêmica; 2009. https://doi. org/10.7476/9788579830099

25. Ceccim RB, Feuerwerker LCM. O quadrilátero da formação para a área da saúde: ensino, gestão, atenção e controle social. Physis. 2004;14(1):41-65. https://doi.org/10.1590/S0103-73312004000100004 